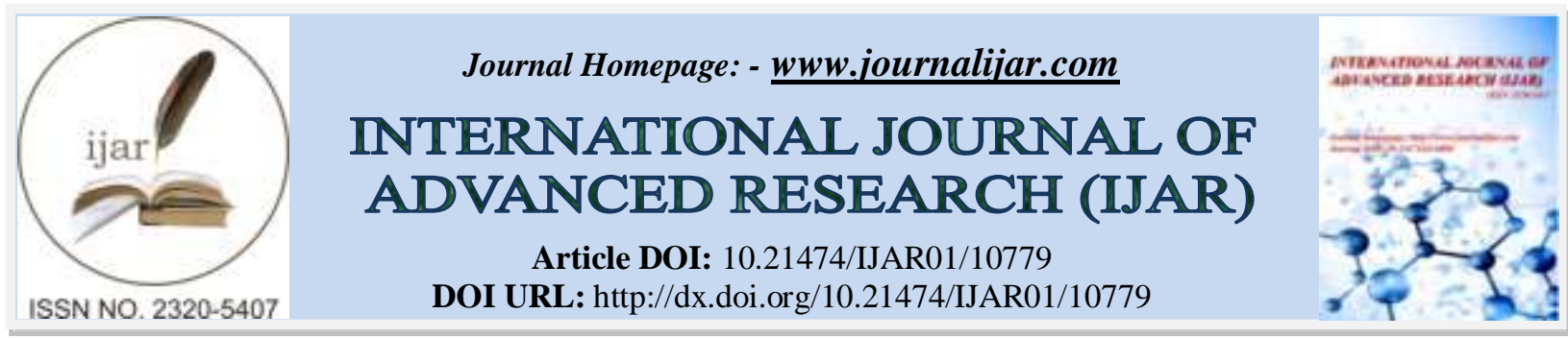

RESEARCH ARTICLE

\title{
AN ASSESSMENT OF PHYSICO-CHEMICAL QUALITY AND BACTERIAL CONTAMINATION OF FAECAL ORIGIN IN GROUND WATER RESOURCES OF RURAL AREAS OF UJJAIN
}

Vikas Parmar and Dr. Madhubala Purohit

Department of Botany, Government Madhav Science P.G.College, Ujjain, M.P. India.

\section{Manuscript Info \\ ........... \\ Manuscript History \\ Received: 10 February 2020 \\ Final Accepted: 12 March 2020 \\ Published: April 2020 \\ Key words:- \\ World Health Organization, Bacterial \\ Contamination of Faecal Origin, \\ Potablity, Ground Water Quality}

\begin{abstract}
Physico-chemical characteristics play a very important role in determining the potability of drinking water. Quality of drinking water used in rural areas of Ujjain was assessed by determining various physico-chemical characteristics of ground water. Bacterial contamination in ground water is assessed by using $\mathrm{H}_{2} \mathrm{~S}$ strip test. Temperature and $\mathrm{pH}$ were within the permissible limit but chloride value of 16 samples (out of 27 samples) crossed the maximum permissible limit $(200-300 \mathrm{mg} / \mathrm{L})$. Total hardness values of 12 samples were reported beyond the permissible limit. Turbidity value of kamed hand pump water sample was $13.1 \mathrm{NTU}$ which is higher than the standard of drinking water quality. $\mathrm{H}_{2} \mathrm{~S}$ strip test were found to be positive in 13 samples in which maximum contamination were reported in well samples.

Copy Right, IJAR, 2020,. All rights reserved.
\end{abstract}

\section{Introduction:-}

Water is one of the important natural resource that sustains all the kind of life on earth. According to National Environment Research Council Report (2007) 71\% of earth surface is covered with water but fresh water is limited only $3 \%$. Ground water constitute more than $90 \%$ of fresh water (Behaila,et.al.2017). Therefore it has been generally used for drinking, domestic and agriculture purposes.

Extensive survey was carried out by the author in study area, reported more than $90 \%$ population of rural resident of Ujjain were largely depends upon ground water resources for drinking and domestic purpose. As there is no regular water supply in these area. Therefore the quality of ground water used by rural resident of Ujjain is great concern to their health. Hence present study was carried to assess:-

The Physico-chemical characteristics of ground water like- Temperature, $\mathrm{pH}$, Turbidity,TDS, Total hardness, chloride.

The bacterial contamination of faecal origin.

\section{Material and Methods:-}

\section{Sample collection :}

Total 27 ground water samples (9 wells, 9 bore wells and 9 hand pumps) were collected from three sub areas of Ujjain viz. mangalnath road, barnagar road and indore road of Ujjain in November 2016.

\section{Corresponding Author:- Vikas parmar}

Address:- Department of Botany, Government Madhav Science P.G.College, Ujjain, M.P. India. 
Sampling was done in the early morning. For physico-chemical analysis samples were collected in good quality of plastic containers. To assess the bacterial contamination, ground water samples were collected in $\mathrm{H}_{2} \mathrm{~S}$ testing bottle (A readymade field testing kit). After collection, samples were immediately labelled and bought to the laboratory for further analysis.

\section{Samples analysis:}

Analysis of physico-chemical characteristics:

All samples were analyzed for various physico-chemical parameters by following standard methods of APHA(1992). Colour was noted by experience and other parameters like Temperature, pH, Turbidity,TDS, Total hardness, chloride were determined by methods given in table 1 . The recorded data were compared with standard values (Table 2) recommended by ICMR(1975), BIS (2012) and WHO(2011).

\section{Analysis for bacterial contamination:}

For the analysis of presence of bacteria of faecal origin, ground water samples were filled in $\mathrm{H}_{2} \mathrm{~S}$ testing bottle up to the mark. Incubate the bottle for $24-48 \mathrm{hrs}$ at $37^{0} \mathrm{C}$. Change in the colour was recorded.,,,++++++++++ indicate the degree of contamination $((-) \mathrm{No},(+)$ slight, $(++)$ moderate, $(+++)$ high, $(++++)$ very high contamination).

\section{Results and Discussion:-}

Results of physico-chemical analysis of ground water samples of rural areas of Ujjain was showed in Table- 3, 4, 5.

\section{Temperature:}

Temperature is an important biologically significant factor which play an important role in the metabolic activities of the organism (Prasad,et.al,2014). WHO did not recommended definite value for the temperature, however BIS (1991) recommended $40^{\circ} \mathrm{C}$ is the permissible limit of drinking water. In study area slight variation in the temperature $\left(23.8^{\circ} \mathrm{C}-25.8^{0} \mathrm{C}\right)$ were recorded. It may be due to the difference in timing of sample collection.

pH:

$\mathrm{pH}$ is an important ground water quality parameter due to the sensitivity of organism to the $\mathrm{pH}$ of their environment. As per the standards (WHO,2011) $\mathrm{pH}$ of drinking water must ranged 6.5-8.5. Hence all ground water samples were found within the permissible limit. Mostafa,et.al (2013) also reported same result in ground water samples in Egypt.

\section{Turbidity:}

The value of turbidity varies from 0.1 - 13.1 NTU. As per standards of drinking water quality its value must below 1NTU and where resources are scared its value not crossed 5NTU. In kamed hand pump water sample turbidity was too high (13.1NTU). Sunita, R. Dandawate reported turbidity value higher in four out of five ground water samples in post monsoon season in Kopargaon area of Maharastra.

\section{Total dissolved solid (TDS):}

The most important aspects of drinking water is its taste (Bruvold and pangborn,1966). Higher value of TDS reduces utility for drinking, irrigation and industrial purpose (Pandya,et.al.,2013). In present study TDS ranges from 436 $1960 \mathrm{mg} / \mathrm{L}$. Water samples from two bore well viz. kamed and goyala chowki TDS recorded above the permissible limit while in well water sample of jawasiya its value was noted below the minimum acceptable limit. Sowrabha and Narayana (2014) assess the ground water quality used for drinking purpose in shivamogga town, Karnataka reported TDS value in all samples within the permissible limit .

\section{Total hardness:}

According to some classification water with hardness $0-75 \mathrm{mg} / \mathrm{L}$ is classified as soft, $76-150 \mathrm{mg} / \mathrm{L}$ is moderate, $151-300 \mathrm{mg} / \mathrm{L}$ is hard and more than $300 \mathrm{mg} / \mathrm{L}$ is very hard (Saravanakumar and Ranjith kumar,2011). In study area hardness value ranged between $260-1630 \mathrm{mg} / \mathrm{L}$. 5 wells, 4 bore wells and 3 hand pumps water samples hardness value exceed the WHO standards. The high concentration of total hardness may cause heart disease and kidney problem (jain,et.al.,1997). Satyavani,et.al.(2013) reported hardness value 500-1300mg/L in pre monsoon and 800$1600 \mathrm{mg} / \mathrm{L}$ in post monsoon season, exceeded the permissible limit.

\section{Chloride:}

Chloride is the most common inorganic anion present in water (Sudha and sangeetha,2017) but higher values in drinking water serve as indicator of sewage pollution and unacceptable for human for human consumption 
(Ananthakrishnan,rt.al,2012). In water samples chloride concentration varies from 190 -1201mg/L. Therefore only 1 well, 3 bore wells and 4 hand pumps samples were reported as per WHO standards (200 -300mg/L). Satyavani,et.al.(2013) studied the physicochemical and microbial analysis of ground water samples recorded higher values of chloride in 3 ground water samples in pre monsoon and 2 in post monsoon season.

\section{Bacterial contamination:}

Presence of bacterial contamination of faecal origin in the ground water samples of different rural areas of Ujjain was tested by $\mathrm{H}_{2} \mathrm{~S}$ strip test. Total 27 samples were tested in which 13 (7 wells (54\%), 3 bore wells (23\%) and 3 hand pumps(23\%)) samples were reported contaminated as $\mathrm{H}_{2} \mathrm{~S}$ strip test (fig 2.) were found to be positive there. Singh,et.al.(2017) recorded bacterial contamination in 58 samples (out of 67 samples) from urban areas of Patna, Bihar.

\section{Conclusion:-}

Physico-chemical analysis of ground water samples concluded that turbidity, TDS, total hardness and chloride values has been crossed the maximum permissible limit of drinking water quality as per WHO (2011) standards. Higher the value of TDS decreases the solubility of oxygen enhance eutrophication. Total hardness values of 13 samples were reported beyond the permissible limit. It might be due to dissolve carbon dioxide release by bacteria present in water. In 5 wells, 6 bore wells and 5 hand pumps sample chloride value higher than permissible limit (fig.1.) indicated that resources might be contaminated by sewage. Results showed that in most cases were Physicochemical characteristics of the ground water samples were not as per the standards $\mathrm{H}_{2} \mathrm{~S}$ strip test were found to be positive.

Table 1:- Methods Used for the Analysis of Various Quality Parameters of Ground Water Samples of Ujjain.

\begin{tabular}{|l|l|l|l|}
\hline S. No & Parameter & Units & Method used \\
\hline 1 & Colour & - & By experience \\
\hline 2 & Turbidity & NTU* & By nephelometer \\
\hline 3 & Temperature & ${ }^{0} \mathrm{C}$ & Thermometer \\
\hline 4 & pH & - & Digital pH-meter \\
\hline 5 & Total dissolved solid (TDS). & $\mathrm{Mg} / \mathrm{l}$ & By TDS meter \\
\hline 6 & Total hardness & $\mathrm{Mg} / \mathrm{l}$ & By EDTA titrimetric method. \\
\hline 7 & Chloride & $\mathrm{Mg} / \mathrm{l}$ & By Argentrometric method \\
\hline
\end{tabular}

*-Nephelometric turbidity units

Table 2:- Various Standards of Ground Water Quality parameters.

\begin{tabular}{|l|l|l|l|l|}
\hline \multirow{2}{*}{ S.No } & PARAMETERS & \multicolumn{3}{l|}{ STANDARDS OF GROUND WATER } \\
\cline { 3 - 5 } & & WHO (2011) & BIS (2012) & ICMR (1975) \\
\hline 1 & $\mathrm{pH}$ & $6.6-8.5$ & $6.6-8.5$ & $6.0-8.5$ \\
\hline 2 & Colour & - & - & - \\
\hline 3 & Turbidity(NTU) & $1-5$ & $5-10$ & $2.5-10$ \\
\hline 4 & TDS(mg/100ml) & $500-1500$ & $500-2000$ & $500-3000$ \\
\hline 5 & $\begin{array}{l}\text { Total Hardness } \\
(\mathrm{mg} / 100 \mathrm{ml})\end{array}$ & $200-600$ & $200-600$ & $200-600$ \\
\hline 6 & $\begin{array}{l}\text { Total Chloride } \\
(\mathrm{mg} / 100 \mathrm{ml})\end{array}$ & $200-300$ & $250-1000$ & $200-1000$ \\
\hline 7 & Coliform (cfu/100ml) & 0 & 0 & 0 \\
\hline
\end{tabular}

Table 3:- Impact of PhysicoChemical Characterstics on Faecal Contamination of Ground Water Resources of Rural Area (Mangalnath Road) of Ujjain.

\begin{tabular}{|l|l|l|l|l|l|l|l|l|l|l|}
\hline S.No. & Sub area & Resources & Temp. $\left.{ }^{\mathbf{0}} \mathbf{C}\right)$ & $\mathbf{p H}$ & Colour & $\begin{array}{l}\text { Turbidity } \\
(\mathbf{N T U})\end{array}$ & $\begin{array}{l}\text { TDS } \\
(\mathbf{m g} / \mathbf{l})\end{array}$ & $\begin{array}{l}\text { TH } \\
(\mathbf{m g} / \mathbf{l})\end{array}$ & $\begin{array}{l}\text { Chloride } \\
(\mathbf{m g} / \mathbf{l})\end{array}$ & $\mathbf{H}_{2} \mathbf{S}$ \\
\hline \multirow{2}{*}{1} & \multirow{2}{*}{ Ankpat } & Well & 24 & 7.04 & Clear & 0.3 & 1244 & 1320 & 1201 & + \\
\cline { 3 - 11 } & & BW & 24 & 7.3 & Clear & 0.3 & 1131 & 560 & 595 & - \\
\cline { 3 - 10 } & & HP & 24 & 6.92 & Clear & 1.8 & 1251 & 592 & 1151 & - \\
\hline 2 & \multirow{2}{*}{ Mangalnath } & Well & 24.3 & 6.94 & Clear & 0.4 & 830 & 670 & 360 & + \\
\cline { 3 - 10 } & & BW & 24 & 7.04 & Clear & 0.4 & 882 & 560 & 365 & + \\
\hline
\end{tabular}




\begin{tabular}{|l|l|l|l|l|l|l|l|l|l|l|}
\hline & & HP & 24 & 7.2 & Clear & 2.6 & 913 & 470 & 260 & + \\
\hline \multirow{3}{*}{3} & \multirow{3}{*}{ Kamed } & Well & 24 & 7.2 & Clear & 0.4 & 720 & 520 & 190 & + \\
\cline { 3 - 12 } & & BW & 23.9 & 6.86 & Clear & 0.1 & 1960 & 1628 & 1061 & - \\
\cline { 3 - 11 } & & HP & 24 & 6.95 & Turbid & 13.1 & 1256 & 1470 & 961 & - \\
\hline
\end{tabular}

Note $-:$ Temp. $=$ Temperature, $\mathrm{TDS}=$ Total dissolve solid, TH=Total hardness, BW=Bore well, HP= Hand pump

Table 4:- Impact of PhysicoChemical Characterstics on Faecal Contamination of Ground Water Resources of Rural Area (Barnagar Road) of Ujjain.

\begin{tabular}{|c|c|c|c|c|c|c|c|c|c|c|}
\hline S.No. & Sub area & Resources & Temp. $\left({ }^{0} \mathbf{C}\right)$ & pH & Colour & $\begin{array}{l}\text { Turbidity } \\
\text { (NTU) }\end{array}$ & $\begin{array}{l}\text { TDS } \\
(\mathrm{mg} / \mathrm{l})\end{array}$ & $\begin{array}{l}\text { TH } \\
(\mathrm{mg} / \mathrm{l})\end{array}$ & $\begin{array}{l}\begin{array}{l}\text { Chloride } \\
(\mathrm{mg} / \mathrm{l})\end{array} \\
\end{array}$ & $\mathbf{H}_{2} \mathrm{~S}$ \\
\hline \multirow[t]{3}{*}{1} & \multirow{3}{*}{ Jawasiya } & Well & 24 & 7.4 & Clear & 0.3 & 436 & 428 & 110 & + \\
\hline & & BW & 24 & 7.3 & Clear & 0.1 & 714 & 420 & 294 & - \\
\hline & & HP & 24 & 7.3 & Clear & 4.5 & 842 & 260 & 294 & + \\
\hline \multirow[t]{3}{*}{2} & \multirow[t]{3}{*}{ Mullapura } & Well & 24.2 & 6.95 & Clear & 0.4 & 882 & 680 & 390 & + \\
\hline & & BW & 24.1 & 7.47 & Clear & 0.3 & 862 & 380 & 430 & - \\
\hline & & $\mathrm{HP}$ & 24.1 & 7.27 & Clear & 0.2 & 910 & 360 & 475 & - \\
\hline \multirow[t]{3}{*}{3} & \multirow[t]{3}{*}{ Gonsa } & Well & 23.9 & 7.52 & Clear & 1.4 & 1212 & 1390 & 1151 & + \\
\hline & & BW & 23.8 & 7.3 & Clear & 0.2 & 1130 & 730 & 916 & - \\
\hline & & HP & 23.8 & 7.24 & Clear & 0.9 & 1170 & 1080 & 976 & - \\
\hline \multirow[t]{3}{*}{4} & \multirow[t]{3}{*}{ Sadawal } & Well & 24.3 & 7.29 & Clear & 0.3 & 994 & 610 & 435 & - \\
\hline & & BW & 24 & 7.14 & Clear & 0.2 & 812 & 650 & 280 & + \\
\hline & & HP & 24 & 7.12 & Turbid & 4.1 & 762 & 540 & 285 & + \\
\hline \multirow[t]{3}{*}{5} & \multirow[t]{3}{*}{ Ajampura } & Well & 24 & 7.58 & Clear & 0.4 & 546 & 450 & 145 & - \\
\hline & & BW & 24 & 6.85 & Clear & 0.3 & 1207 & 1630 & 791 & - \\
\hline & & HP & 24 & 7.3 & Clear & 0.4 & 978 & 780 & 385 & - \\
\hline
\end{tabular}

Note -: Temp. $=$ Temperature ,TDS= Total dissolve solid, TH=Total hardness, BW=Bore well, HP= Hand pump

Table 5:- Impact of PhysicoChemical Characterstics on Faecal Contamination of Ground Water Resources of Rural Area (Indore Road) of Ujjain.

\begin{tabular}{|l|l|l|l|l|l|l|l|l|l|l|}
\hline S.No. & $\begin{array}{l}\text { Sub } \\
\text { area }\end{array}$ & Resources & Temp. $\left.{ }^{\mathbf{0}} \mathbf{C}\right)$ & $\mathbf{p H}$ & Colour & $\begin{array}{l}\text { Turbidity } \\
(\mathbf{N T U})\end{array}$ & $\begin{array}{l}\text { TDS } \\
(\mathbf{m g} / \mathbf{l})\end{array}$ & $\begin{array}{l}\text { TH } \\
(\mathbf{m g} / \mathbf{l})\end{array}$ & $\begin{array}{l}\text { Chloride } \\
(\mathbf{m g} / \mathbf{l})\end{array}$ & $\mathbf{H}_{2} \mathbf{S}$ \\
\hline 1 & \multirow{2}{*}{$\begin{array}{l}\text { Goyala } \\
\text { Chauki }\end{array}$} & Well & 25 & 6.85 & Clear & 0.2 & 816 & 520 & 282 & +++ \\
\cline { 2 - 10 } & & BW & 24.9 & 6.98 & Clear & 0.2 & 1670 & 512 & 290 & + \\
\cline { 2 - 10 } & & HP & 24.8 & 7.03 & Clear & 0.2 & 1140 & 380 & 276 & - \\
\hline
\end{tabular}

Note -: Temp.= Temperature ,TDS $=$ Total dissolve solid, TH=Total hardness, BW=Bore well, HP= Hand pump

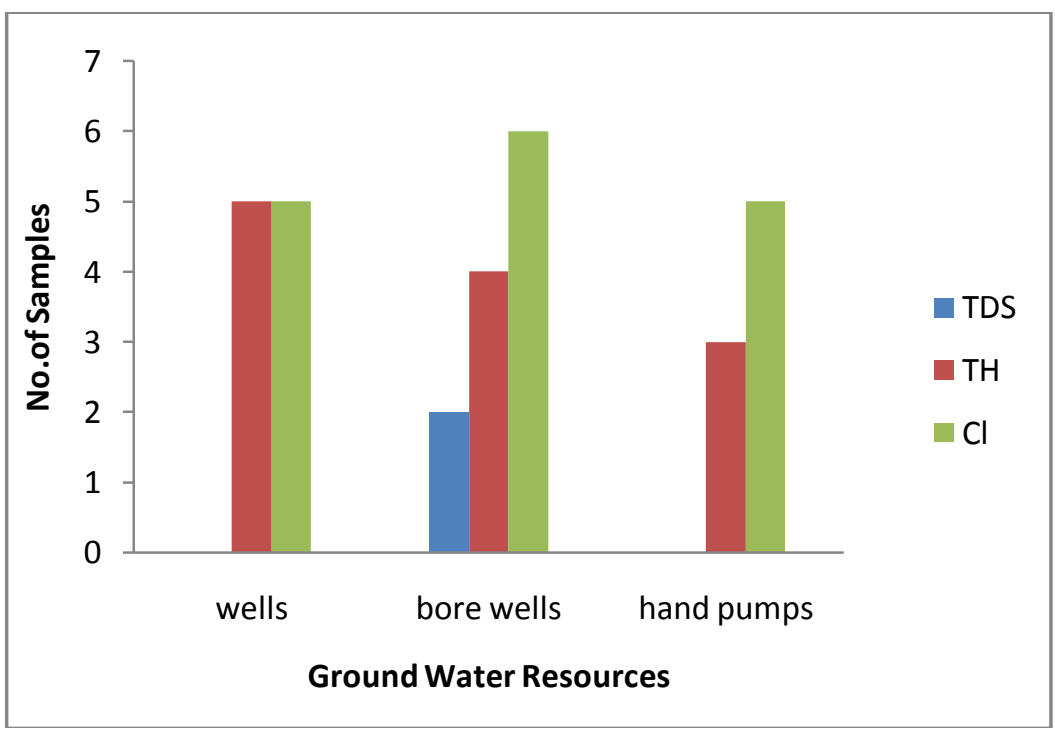

Fig.1:- No. of ground water samples showing TDS, TH, $\mathrm{Cl}$ values above permissible limits. 


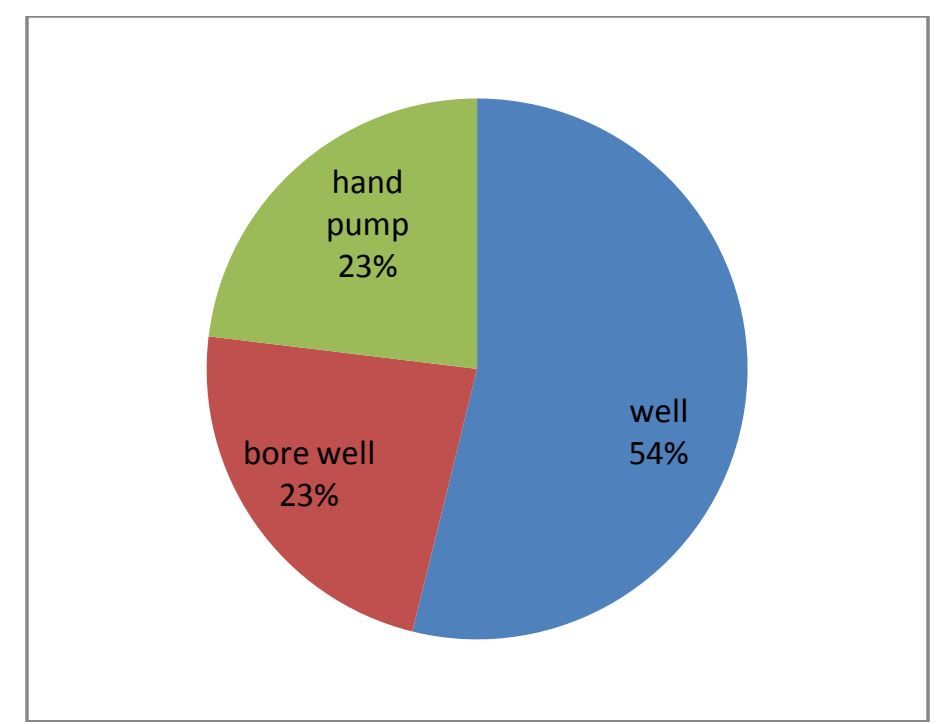

Fig. 2:- Ground water resources showing bacterial contamination.

\section{References:-}

1. Amr H.Mostafa, Raed S.Al - Wasify, Amr M.Sayed and Bakry M. Haroun,(2013) microbiological and physicochemical evaluation of ground water in Egypt, International journal of Environment and Sustainablity, vol.2, No.2,pp 1-10.

2. Ananthakrishnan,S., loganathan,K and Jafer Ahamed,A(2012). Study on ground water quality and its sustablity for drinking purpose in Alathur block- perambular district, Tamilnadu, India.pp1332-1338.

3. APHA (1992). Standards methods for examination of water and waste water, $18^{\text {th }}$ Edition. APHA Washington D.C.

4. Bruvold,W.H and Pangborn,R.M(1966). Rated acceptability of mineral taste in water, J.Appl. Psycho., $50(1), 22$.

5. Jain,C.K., Shamia,M.K and Omkar(1997). Indian journal of Enviornmental protection. 17(6), 401-405.

6. National Environment Research council (2007). The oceans: Scientific certainties and uncertainties. Swindon, England.

7. Pandya,S.N., Rana,A.K. and Bhoi, D.K.,(2013). Assessment of drinking water quality of rural parts of Kapadwanj and its impact on human health, curr. World Environ., 8(1): 153-156.

8. Prasad,M, Muralidhara Reddy,B., Ramakrishna Reddy,M and V. Sunitha (2014). Int.J.Curr.Res.Aca.Rev.2(12): 31-41.

9. Saravana kumar,K.,Ranjith kumar,R.(2011),Analysis of water quality parameters of ground water near Ambattur Industrial area, Tamilnadu, India, Indian J.Sci.Technol.,4(5):pp.560-562.

10. Satyavani, ch vv,B venkateswararao and PVS Machi Raju (2013) Physicochemical and microbial analysis of ground water near municipal dump site for quality evaluation, International journal of Bioassays,02 (08);11391144.

11. Singh,S.,kanth,M.,Kumar,D.,Raj,R.,Kashyap,A.,Jha,P.,Anand,A.,Kumari,P.,Ali,Y.,Lokesh,R. $\quad$ and Kumar,S(2017). Physicochemical and bacteriological analysis of drinking water samples from urban areas of Patna district,Bihar, India. Int.J.Life.Sci.Scientific.Res.,3(5):1355-1359.

12. Sudha, R and Sangeetha,T(2017). Comparative study of water quality parameters of lake water (Chinna Eri) with surrounding bore well water samples, Thuraiyur (Tk), Tiruchirappalli(Dt.), Tamilnadu.international journal of current research in chemistry and pharmaceutical sciences, 4(7): 14-18.

13. Sunita R.Dandwate(2012), Study of Physicochemical parameters of ground water quality of Kopargaon area,Maharastra state,India during pre-monsoon and post monsoon seasons, E-journal of chemistry,9(1), 15-20. 